\title{
RICE (ORYZA SATIVA LINN.) FIELD WEEDS AND ITS ETHNOMEDICINAL IMPORTANCE IN EAST VIDARBHA (M.S.)
}

\author{
Suryawanshi, B.G. and Rane, V.I. \\ Jagat Arts, Commerce and Indiraben Hariharbhai Patel Science College Goregaon, Dist. \\ Gondia. (M.S.) 441801 \\ Email:-suryawanshi.bg@gmail.com, vijay_rane@rediffmail.com
}

Communicated : 15.12 .19

Revision : 03.01.2020

Accepted : 22.01.2020

Published: 30.01 .2020

\begin{abstract}
:
Present study is carried out in kharif and rabbi cropping seasons in east Vidarbha, Maharashtra. The study was based on extensive and intensive fields surveys made during different months during 2018-2019.During the course of field study the authors have selected 4 important rice growing blocks.It divided into two parts. $\mathrm{S}_{1}$ (irrigated) sitecontaining the blocksGoregaon (District-Gondia) and Lakhandur (District-Bhandara). $\mathrm{S}_{2}$ (non-irrigated) site containing blocks Deori and Arjuni/ Mor (District-Gondia).Frequent field trips were made twice a month in each site for collection of weeds. During this period the authors have reported a total of 66 weed species belonging to 21 angiospermic and 1 pteridophytic families. Out of 21 angiospermic families the predominance was shown by monocot families like Cyperaceae and Poaceae having 14and 12 weed species, respectively. The pteridophytic family Marsileaceae was represented by 01 weed species. The object of this work is to gather such information on the rice-field weeds and to show that most of these haveethnomedicinal importance. It has also been observed that 24weeds having ethnomedicinal properties. The family like Amaranthaceae, Asteraceae and Poaceae had the largest number of plants used for dysentery, wounds and skin diseases. Further phytochemical investigation is necessary before some of them can be used as drugs to serve mankind. It is the need of the hour to explore, identify and utilize new ethnomedicinal plants and help to support increase the economy of farmer of the rural area.
\end{abstract}

Key words: - Rice, Weeds, Kharif, Rabbi, Yield, Ethnomedicine.

\section{INTRODUCTION:}

The FAO considers rice to be most important human food crop in the world. For half of the world population, particularly in Asia, America, and Africa rice supplies $80 \%$ of their food requirements. Rice plays role of paramount importance in the diet of Asian population, particularly in the India. India is one of the largest rice growing country in the world and having greatest consumers. It has 43.20 million hectares land under rice cultivation. Total global consumption of milled rice amounted to approximately 499.2 million metric tons. In Asia yield is680.1 million metric tonsand in India 148.26 million metric tons estimated rice production (FAO, 2017).
In India rice is grown on about $4,49,72,000$ hectares, $30 \%$ of the total area under food grains and $37 \%$ of the total area under cereals. Over 30,000 varieties of rice are cultivated in different part of India. The production of rice in India is $89,475.1$ thousand metric tons with an average yield of $2,404 \mathrm{Kg} / \mathrm{ha}$. as per the record of Annual report of Agriculture, New Delhi 20162017). The average per hectare yield of rice in India is less as compared to China due to many factors like shortage and high cost labor; lack of irrigation facilities, quality of germplasm, agricultural output and ecological conditions etc., but the problems of weed is the major contributor in the loss of production. Weed is a plant which is judged by man to be not of use and undesirable at a place where it 
flourishes (Patilet al., 2010). The weeds that grow along with rice crop results in low agricultural output. They are the major barriers to rice production because of their ability to compete for $\mathrm{CO}_{2}$, space, moisture, sunlight and nutrients. Weedy crop sometimes leads to complete failure (Singh et al., 2005). Out of total losses due to various biotic factors weeds are known to account for one third (Rao and Nagamani, 2007). It has been observed that grain yield in rice is drastically reduced if it is not deweeded at early stage of growth.Rice provides $23 \%$ of global human per capita energy and $16 \%$ per capita protein. Rice protein ranks high in nutritional quality among cereals, though protein content is modest(Shah Alam, 2014).India is the second largest producer of rice after China (Savaryet al., 2005). Beside its use for human food, rice is a source for number of industrial products like rice starch, rice branoil, flaked rice, puffed rice and rice husk etc. Being staple food it plays an important role in the economy of India hence occupies a central position in agricultural policy making (Dangwalet al., 2012).

Rice crop cultivated in two seasons, kharif and rabbi. The kharif season commence from June to November while rabbi from middle January to May. Occurrence of weeds in rice field is based on favourableecological factors. In view of recent demand it is essential to intensify the utilization of weeds as medicinal plants and support to increase the economy of farmers.

\section{MATERIAL AND METHODS:-}

The present study deals with major weeds of rice fields in east Vidarbha, Maharashtra. The study was based on extensive and intensive fields surveys made during different months of cropping seasons 2018-2019. Frequent field trips were made twice a month in each site for collection of weed species (Fig. 1\& Plate-1). During this course of interviews were conducted with farmers and agriculturalists of each site about seasonal weed species. Flowering, fruiting seasons and ethno-medicinal uses of weeds were reported. The collected weed plants were properly identified with the help of available literature offlorasand compared with Google lens(Dangwalet al.,2012).

\section{RESULTS AND DISCUSSION}

In ancient Indian literature, it is mentioned that every plant on the earth is useful for human being, crops and animals. Rice fields are rich in biological diversity. Weeds can act as allelophathic effects. The term Allelopathy means the injurious effects of one upon another. Positive (inhibitory) allelopathic effects of any weed on other weeds can be exploited to developseco-friendly, cheap and effective green herbicides. It contains green allelochemicals which are an integral part of eco or organic farming (Oudhiaet al.,2002). Hereported the floristic composition of the area and may act as green herbicide. Ecological study of rice, weeds was documented. Total 208 plant species were recorded in rice field, which includes Herbs-118, Shurbs-31, under Shrub-2, Trees-39, Twiner-5, and Climber-13. In these 208 plants, 173 genera, 208 species belong to 63 families.He was also noted that many farmers are sale these useful weeds to local markets after uprooting. This is providing an additional income to the farmers. The study suggested that by educating the farmers and local people about proper grading and processing of different weed parts and establishing village level cooperative societies, one can provide a strong base for them to startsmall cottage industries and also a good market price of their products.

Ethno-medicine and their traditional knowledge is a good illustration of poor communities living in theremote areas, fighting even incurable diseasesthrough the traditional methods and even for theirlivestock through these traditional herbal medicines(Rautet al., 2012). Plant parts are directly used asmedicines by a majority of community in all over world and have no side effect like allopathic medicines. Most of the modern medicines are produced indirectly from medicinal plants. In the state ofOdisha, phytotherapy (treatment with medicines from plant and their derived products) forms an integral part of the local culture, and the information about plants and their uses are passed from generation to generation through oral folklore, primarily amongst the elderly; the natural retainers of traditional knowledge in 
their respective communities (Rautet al., 2012).

Rice is the important crop grown in these districts. Regular cultivation are practiced, but the per hector yield of rice in this district is less as compared to other parts of India due to many factors out of which the problem of weeds is of great concern. The persistent weed species give a severe competition to rice crop and reduce the agricultural output. Some weeds are difficult to identify at early stage (Before flowering) because of their resemblance with crop plants.Cyperaceae and Poaceae are dominant and act as associate in rice field(Table-1). FamilyCyperaceae i.e., Cyperusrotundus, C. iria and C.difformis,C.odorantus, C. pilosusetc. were dominant. However some of the weeds reported from the study area i.e., Achyranthesaspera, Eclipta alba, Commelinabenghalensis, Cynodondactylon, Euphorbia hirta, Amaranths virdis, Cyperusrotundus, Ammaniabaccifera ,Ludwigiaparviflora, Mollugopentaphylla, Eleusineindica, Phyllanudifloraetc. are of medicinal importance, used in traditional medicines by vaidhyas of these area.

The weeds like Amaranthus viridis, Boerhaavia diffusa, Trianthemaportulaca strum, Portulaca oleracea, Oxalis corniculata etc. are used in some cooking racepies. Ophiuru scorymbosus and Paspalum distichumare antioxidant. Other 42 weed species used as fodder for domestic animals. Biomass from weeds is also suggested to use for compost and green manure.

Medicinal plants constitute the base of health care systems in many societies. Globally, about $85 \%$ of the traditional medicines used for primary healthcare derived from plants (Farnsworth, 2012). Today, a c cording to the World Health Organization (WHO), as many as $80 \%$ of the world's people depends on traditional medicine and in India, $65 \%$ ofthe population in the rural areas use Ayurveda (WHO, 2002). In the interior areas of Koraput district, plants become the only source of medicine because lack ofmodern facilities and remoteness (Pattnaik and Mohapatra
2010). Ironically, information on the useof plants for medicine from that area is completely lacking. At the same time, the traditional knowledgeis rapidly degrading due to modernization of that area and the younger generation is not interested tolearn from older generation. Thus, much important information may have been lost in absence of properdocumentation. Rautet al. (2012) reported several ethnobotanical plants inthe Semiliguda of Koraput district of Odisha.

\section{CONCLUSION}

The present study was conducted as a first ever attempt from the study area to explore and identify the66 species ofweeds belong to 22 families in the field ofrice crop. This will help the farmers and agriculturists to identify the weeds for the planning of their control. Weeds compete with rice crop for nutrition and hence reduce the yield. They also affect the quality of germplasm and cause enormous loss to the farmers. It is essential to intensify the utilization of weeds as medicinal plants. These weeds provide ample opportunities to study them critically for new drug development through chemical analysis without disturbing biodiversity.Further this study will be useful for the acclimatization of weeds into cultivated plants. Generally weed plants are thehost of microbes, and provides habitat for disease causal organisms.After deweeded microbes decompose them and again infect to rice crop. Eradicated weeds need to be used positively for fodder and composting.

\section{REFERENCES}

Dangwal L. R., Singh A., Singh T. and Sharma A. (2012). Major weeds of paddy fields in District Rajouri $\quad(\mathrm{J} \& \mathrm{~K}) \quad$ India. Asian Research Publishing Network (ARPN). Vol. 7:527- 532. 
Dhanam, S. and B. Elayaraj(2014): Ethnomedicinal aspects of someweeds from paddy fields of Villupuram district in Tamil Nadu, India. International Letters of Natural Sci.14:1-10.

Farnsworth, N.R. (2012). Screening of plants for New Medicine. In: Biodiversity, Wilson, E.O. (Ed.). National Academy Press, Washington DC, 83-97.

Oudhia, P.; Pal, A.R. and Pali, G.P. (2002):Traditional

Medicinal

Knowledge About Common Crop Weeds In Bagbahera (India) Region: A Survey. Agric. Sci. Digest, 22 (1) : 53 - 54,

Patil P. S., Ahirrao Y.A., Dusing Y.A., Aher V.P. and Patil D.A. (2010). Role of crop weeds in traditional medicines in Buldhana district (Maharastra). Life sciences leaflets. 10: 261- 272.

Pattanaik C., Reddy C.S., Murty M.S.R., Reddy P. (2006). Ethanomedicinal observation among tribal people of Koraput, Orissa, India. Research Journal of Botany. 1 : 125-128.

Rao A.N. and Nagamani A. (2007). Available technologies and future research challenges for managing weeds in dry seeded rice in India. In: Proceeding of the 21st Asian Pacific Weed Science Society Conference 2 to 6 th October, Colombo, Sri Lanka.
Raut, S., Sen, S.K., Satpathy, S. and Pattnaik, D. (2012). An ethnobotanical Survey of Medicinal Plants in Semiliguda of Koraput District, Odisha, India. Botany Research International. 5 (4) : 97-107.

Savary S., Castilla N. P., Elazegui F. A. and Teng P. S. (2005). Multiple effects of two drivers of agricultural change, labour shortage and water scarcity on rice pest profiles in tropical Asia. Field Crops Res. 91: 263-271.

Singh S., Singh G., Singh V. P. and Singh A. P. (2005). Effect of establishment methods and weed management practices on weeds and rice in ricewheat cropping system. Indian Journal of Weed Science. 37: 51-57.

World Health Organization, (2002). WHO Traditional Medi-cine Strategy Report. Document W H O / ED M / TRM/2002.

http://www.fao.org/economic/RRM, Vol. xx issue No.-1 April, 2017.

www.agricoop.nic.in Department of Agriculture, Cooperation \& Farmers Welfare Ministry of Agriculture \& Farmers Welfare Government of India, New Delhi- Annual report 2016-17 


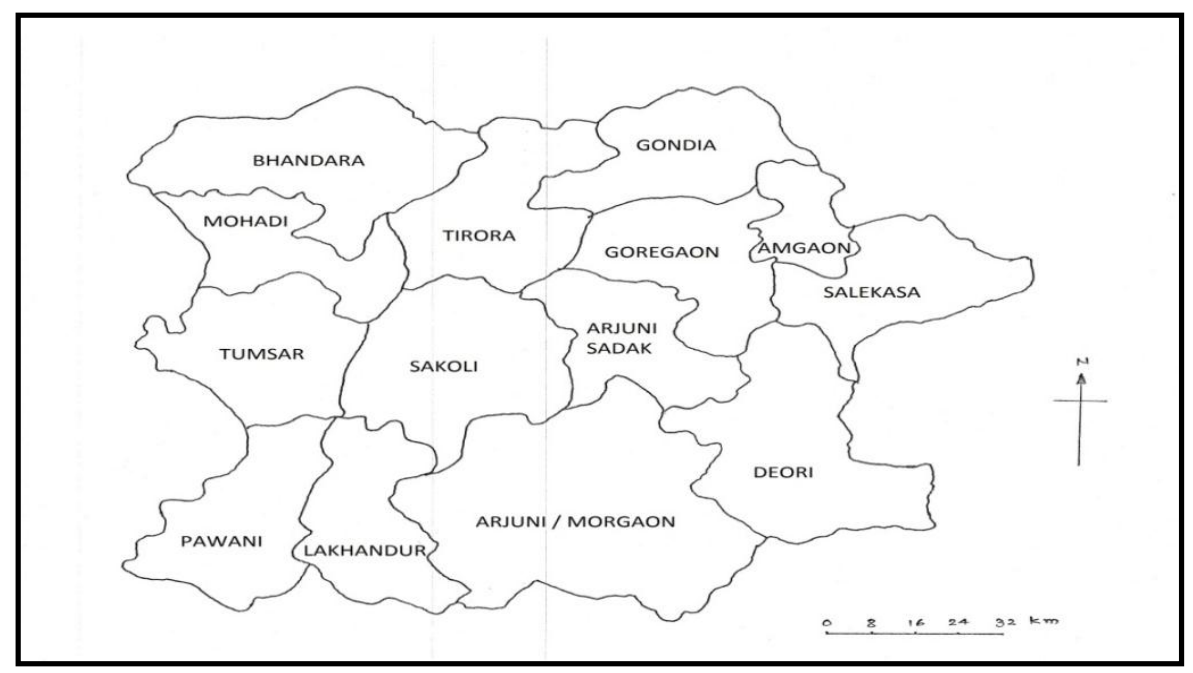

FIG: 1 MAP OF BHANDARA and GONDIA

Table: 1 Rice fields weeds and its uses in East Vidarbha

\begin{tabular}{|c|c|c|c|c|}
\hline $\begin{array}{l}\text { S. } \\
\text { N. }\end{array}$ & Family & Botanical name & $\begin{array}{l}\text { Flowering } \\
\text { period }\end{array}$ & Ethnomedicinal uses \\
\hline \multirow{6}{*}{1} & \multirow{6}{*}{ Amaranthaceae } & Alternantherasessilis (L.) DC. & Feb- Oct & Dysentery \\
\hline & & A.philoxeroides (Mart.) Ariseb & Aug- Nov & Fodder, composting \\
\hline & & Amaranthusviridis $\mathrm{L}$. & Jan- Dec & $\begin{array}{l}\text { Ear disease, skin eruption, } \\
\text { abdominal disorder }\end{array}$ \\
\hline & & Amaranths spinosus L. & July- Dec & Fodder, composting \\
\hline & & Achyranthesaspera L. & Mar- Dec & Root for rheumatisms \\
\hline & & Celosia argentea $\mathrm{L}$. & Aug- Decr & Fodder, composting \\
\hline \multirow{6}{*}{2} & \multirow{6}{*}{ Asteraceae } & Ageratum conyzoides L. & Jan- Dec & Kidney stones,wounds \\
\hline & & Bidensbipinnata L. & Mar- Dec & Fodder, composting \\
\hline & & Eclipta alba L. & Jan- Dec & $\begin{array}{l}\text { Hair, eye, dental \& leprosy } \\
\text { problem, }\end{array}$ \\
\hline & & Galinsogaparviflora Cav. & yearly & Fodder, composting \\
\hline & & PartheniumhysterophorusL. & yearly & Fodder, composting \\
\hline & & VernoniacinareaLees. & July-Dec & Leucoderma,psoriasis \\
\hline 3 & Aizoaceae & TrianthemaportulacastrumL. & Aug- Dec & Fodder, composting \\
\hline 4 & Brassicaeae & Nasturtium officinale R.BR. & Mar- Sept & Fodder, composting \\
\hline \multirow[t]{3}{*}{5} & \multirow[t]{3}{*}{ Commelinaceae } & CommelinabenghalensisL. & July- Nov & $\begin{array}{l}\text { Hemorrhage, fever, rabies, } \\
\text { snake bite, leprosy, skin }\end{array}$ \\
\hline & & CynotisvagaLour. & July-Oct & Fodder, composting \\
\hline & & MurdannianudifloraL. & Aug- Nov & Fodder, composting \\
\hline 6 & Convolvulaceae & Ipomoea aeriocarpa R.BR. & July- Oct & Cooking vegetable \\
\hline \multirow{8}{*}{7} & \multirow{8}{*}{ Cyperaceae } & Cyperusiria L. & Sept- Dec & Fodder, composting \\
\hline & & CyperusodorantusKunth. & Aug.- Nov & Fodder, composting \\
\hline & & CyperuspilosusVahl. & Aug. Nov & Fodder, composting \\
\hline & & Cyperusrotundus L. & July- Dec & $\begin{array}{l}\text { Vomiting,dysentery wounds, } \\
\text { epilepsy, }\end{array}$ \\
\hline & & Cyperusdifformis L. & Aug- Nov & Fodder, composting \\
\hline & & Cyperusesculentus L. & July- Dec & Fodder, composting \\
\hline & & $\begin{array}{l}\text { Cyperusbrevifolius } \\
\text { Hasskarl. }\end{array}$ & Aug- Nov & Fodder, composting \\
\hline & & CyperuscorymbosusRottboell & July- Dec & Fodder, composting \\
\hline
\end{tabular}




\begin{tabular}{|c|c|c|c|c|}
\hline & & Cyperuspaniceus (Rottboell) Boech. & Aug- Sept & Fodder, composting \\
\hline & & Fimbristyliscomplanata (Retz.) Link. & Mar- June & Fodder, composting \\
\hline & & Fimbristylisdichtoma L. & June- Nov & Fodder,composting \\
\hline & & Fimbristylisferruginea (L.) Vahl & July- Nov & Fodder, composting \\
\hline & & $\begin{array}{l}\text { Fimbristylisquincuangularis } \\
\text { (Vahl.)Kunth }\end{array}$ & July- Nov & Fodder, composting \\
\hline & & Scripussetaceus L. & Jun- Nov & Fodder, composting \\
\hline \multirow{4}{*}{8} & \multirow{4}{*}{ Euphorbiaceae } & Acalyphaindica $L$. & June- Nov & Anthelmantic, ulcers \\
\hline & & Euphorbia hirta L. & Jan- Dec & $\begin{array}{l}\text { Cough, } \\
\text { asthma,dysentery,UTI }\end{array}$ \\
\hline & & Euphorbia indica Lam. & Sept- Nov & Fodder, composting \\
\hline & & Phyllanthusurinaria L. & yearly & Fodder, composting \\
\hline \multirow[t]{2}{*}{9} & \multirow[t]{2}{*}{ Fabaceae } & Aeschynomeneindica L. & Sept- Dec & Fodder, composting \\
\hline & & Cassia pumila Lam. & Aug- Oct & Fodder, composting \\
\hline \multirow[t]{2}{*}{10} & \multirow[t]{2}{*}{ Lythraceae } & Ammaniabaccifera $\mathrm{L}$ & Aug- Dec & $\begin{array}{l}\text { Snake bite, ulcers, } \\
\text { leucorrhoea }\end{array}$ \\
\hline & & LudwigiaparvifloraL. & Aug- Dec & Fever, ulcer, wound \\
\hline \multirow[t]{2}{*}{11} & \multirow[t]{2}{*}{ Malvaceae } & MalvastrumcoromandelianumL. & yearly & Fodder, composting \\
\hline & & SidaacutaBurm. & July-Dec & Fodder, composting \\
\hline 12 & Marsileaceae & Marseliaquadrifolia L. & Aug-Dec & Fodder, composting \\
\hline 13 & Molluginaceae & Mollugopentaphylla L. & Aug-Nov & Checking bleeding, skin \\
\hline 14 & Nyctaginaceae & Boerhaviadiffusa L & Aug- Dec & Cooking vegetable \\
\hline 15 & Oxalidaceae & Oxalis corniculata L. & yearly & $\begin{array}{l}\text { Cough, dysentery, } \\
\text { leucorrhoea, dandruff }\end{array}$ \\
\hline \multirow[t]{12}{*}{16} & \multirow[t]{12}{*}{ Poaceae } & Cynodondactylon L. & yearly & $\begin{array}{l}\text { puja, menoerrhagia, skin } \\
\text { diseases, }\end{array}$ \\
\hline & & Digitariaciliaris Retz. & Aug- Nov & Fodder, composting \\
\hline & & Echinochloacolona L. & July- Oct & Fodder, composting \\
\hline & & Echinochloa crus-galli L. & Aug- Sep & Fodder, composting \\
\hline & & Eleusineindica L. & July- Nov & $\begin{array}{l}\text { Anthelmintic, astringent, } \\
\text { depurative, } \\
\text { febrifuge, laxative }\end{array}$ \\
\hline & & Imperatacylindrica (L.) P. Beauv. & Sep- Jan & $\begin{array}{l}\text { Brush-making, rope-making, } \\
\text { fuel }\end{array}$ \\
\hline & & OphiuruscorymbosusGertn. & Aug- Nov & Nutritious, antioxidant \\
\hline & & PaspalumdistichumAuct. & Mar- Dec & Nutritious, antioxidant \\
\hline & & Paspalumscrobiculatum L. & July- Dec & Fodder, composting \\
\hline & & Saccharumspontaneum L. & Sept- Nov & Ropes, mats and brooms \\
\hline & & Setariaglauca L. & July- Nov & Fodder, composting \\
\hline & & SetariavirdisL. & July- Nov & Fodder, composting \\
\hline \multirow[b]{2}{*}{17} & \multirow[b]{2}{*}{ Polygonaceae } & Polygonumbarbatum L. & Jan- Dec & Haemorrage, diuretic \\
\hline & & Polygonumhydropiper L. & Jan- Dec & Haemorrage, diuretic \\
\hline 18 & Portulacaceae & Portulacaoleracea L. & Sep -Apr & Cooking vegetable, diabetes \\
\hline \multirow[t]{2}{*}{19} & Rubiaceae & Oldenlandiacorymbosa L. & July- Nov & Fodder, composting \\
\hline & Sapindaceae & CordiospermumhelicacabumL. & July- Nov & Fodder, composting \\
\hline 20 & Scrophulariaceae & Mazuspumilus (Burm F.) Van Steen. & Mar- Nov & Fodder, composting \\
\hline 21 & Solanaceae & Physalis minima L. & July- Nov & Fodder, composting \\
\hline 22 & Verbenaceae & Phylanudiflora L. & Feb- Nov & Ulcer, wounds,asthma \\
\hline
\end{tabular}


I J R B A T, Issue (VIII), Vol. I, Jan 2020: 45-51

A Double Blind Peer Reviewed Journal
OPEN $\bigcirc$ ACCESS

e-ISSN 2347 - 517X

Original Article

PLATE - 1

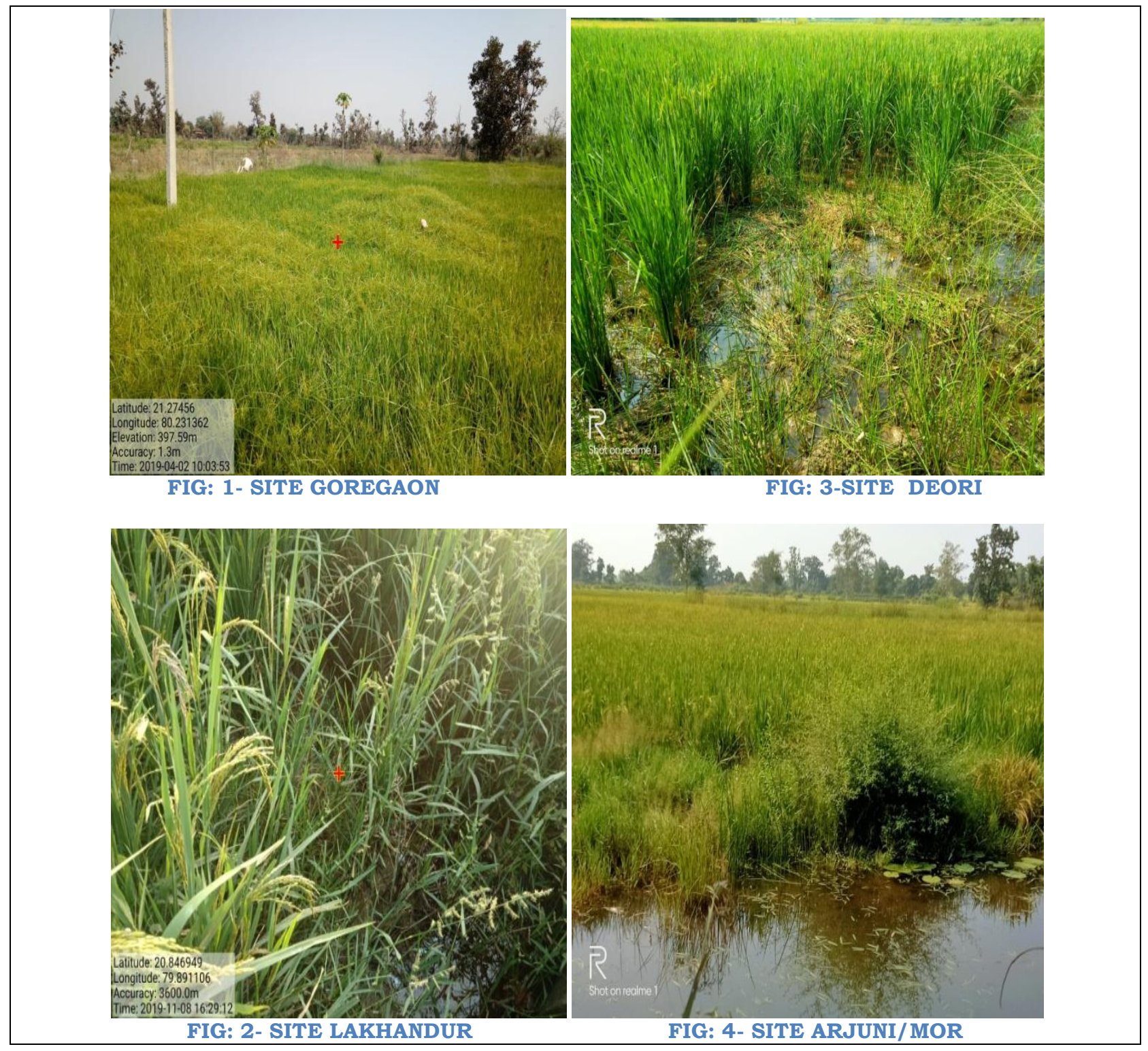

